\title{
PENGUATAN KERJA SAMA INTERNASIONAL DALAM MENGURANGI DAMPAK PANDEMI COVID-19 TERHADAP SEKTOR PERIKANAN DI INDONESIA
}

\author{
Masitha Tismananda Kumala*, Ria Tri Vinata, Peni Jati Setyowati, Titik Suharti \\ Fakultas Hukum Universitas Wijaya Kusuma Surabaya \\ Jl. Dukuh Kupang XXV No. 54, Surabaya 60225 \\ masithatismanandakumala_fh@uwks.ac.id
}

\begin{abstract}
Covid-19 not only has an impact on global public health but also the global economy, including Indonesia. The issues that will be examined in this article are, first, what is the impact of the Covid-19 pandemic on the fisheries sector in Indonesia. Second, what kind of international cooperation which Indonesia can do in improving the economy through the fisheries sector. The research method used is a normative research method with a statute and conceptual approach The conclusion is the Covid-19 pandemic made the number of fishing activities by Indonesian fishing fleets in Indonesian waters is decrease which then triggered foreign fishing fleets to do illegal fishing. Indonesia needs to establish international cooperation also in improving the economy through the fisheries sector during a pandemic.
\end{abstract}

Keywords: Pandemic; Fisheries; International Cooperation.

\begin{abstract}
Abstrak
Covid-19 tidak hanya berdampak pada kesehatan masyarakat global namun juga perekonomian global tidak terkecuali Indonesia. Perekonomian dari berbagai sektor terutama perikanan juga turut terdampak. Permasalahan yang akan dikaji dalam tulisan ini yaitu pertama apakah dampak pandemi Covid-19 terhadap sektor perikanan di Indonesia? Kedua, kerjasama internasional seperti apakah yang dapat dilakukan oleh Indonesia dalam peningkatan perekonomian melalui sektor perikanan? Metode penelitian yang digunakan adalah metode penelitian normatif dengan menggunakan pendekatan perundang-undangan serta pendekatan konseptual. Simpulan yang di dapat adalah pandemi Covid-19 menjadikan sepinya perairan Indonesia dari kegiatan tangkap ikan oleh Kapal Ikan Indonesia yang kemudian memicu Kapal Ikan Asing untuk kembali melakukan illegal fishing. Indonesia juga perlu menjalin kerjasama internasional untuk meningkatkan perekonomian melalui sektor perikanan di masa pandemi.
\end{abstract}

Kata Kunci: Pandemi; Perikanan; Kerja Sama Internasional.

\section{A. Pendahuluan}

Berdasarkan laporan World Health Organization (WHO), kasus Corona Viruses Desease 2019 atau yang lebih dikenal dengan Covid-19 muncul pertama kali pada 8 Desember 2019 di Kota Wuhan, Provinsi Hubei, China (Baskara, 2020). Covid-19 merupakan penyakit yang disebabkan oleh Severe Acute Respiratory
Syndrome Coronavirus 2 (SARS-CoV-2). Sistem penularan dari penyakit ini adalah manusia ke manusia (human to human). Dengan mudahnya orang berpindah dari satu tempat ke tempat lain, dari satu negara ke negara lain, Covid-19 dengan cepat menyebar hingga ke luar China. Terdapat 213 negara di seluruh dunia yang melaporkan adanya kasus Covid-19 di wilayahnya (Putri, 2020). 
Pada tanggal 30 Januari 2020, WHO mengumumkan Darurat Kesehatan Masyarakat Global (Arlinta, 2020). Di Indonesia sendiri, pada tanggal 2 Maret 2020, Presiden Joko Widodo mengumumkan secara resmi kasus Covid-19 pertama di Indonesia (Baskara, 2020). Covid-19 secara cepat menyebar di hampir seluruh wilayah di Indonesia. Dengan melihat kecepatan dan luasnya penyebaran Covid-19 di dunia, WHO menetapkan Covid-19 sebagai Pandemi Global pada tanggal 11 Maret 2020 (Alam, 2020). Jumlah kasus positif Covid-19 di Indonesia hingga tanggal 17 September 2020 adalah sebanyak 228.993 orang (Muttaqin, 2020).

Covid-19 membuat perekonomian global terpuruk. Hal ini disebabkan oleh dua hal. Pertama, penyebaran Covid-19, memaksa masyarakat untuk menjaga jarak satau sama lain. Hal ini menyebabkan banyak kantor, bisnis, acara, perusahaan terpaksa tutup untuk mencegah terjadinya penyebaran Covid-19. Kedua, penyebaran Covid-19 menciptakan kondisi yang tidak pasti termasuk dalam hal investasi ekonomi dan pasar konsumen (Ozili, P.K.; Arun, 2020). China, negara pertama dimana Covid-19 pertama kali muncul, adalah negara yang memiliki peran krusial atas sumber pasokan gobal. Jalannya perekonomian banyak negara bergantung pada China sebagai sumber utama permintaan banyaknya komoditas maupun sumber utama bahan baku produksi. Apabila China menghentikan segala aktifitas perekonomian akibat pandemi Covid-19, maka akan sangat berdampak pada jalannya perekonomian di banyak negara (Acikgoz O ; Gunay, 2020). Dampak yang dirasakan di antaranya seperti penghentian operasional secara sementara maupun permanen, pemotongan gaji karyawan, hingga Pemutusan Hubungan Kerja (PHK). Terganggunya sektor bisnis di antaranya disebabkan terganggunya pasokan bahan baku akibat penutupan akses baik di dalam negeri maupun antar negara, menurunnya daya beli konsumen, serta kebijakankebijakan negara untuk menghentikan impor produk tertentu yang berasal dari negara tertentu.

Indonesia turut merasakan kerugian dalam hal perekonomian di berbagai sektor akibat pandemi Covid-19. Adanya kebijakan Social dan Physycal Distancing menjadikan proses jual beli terhambat. Dampak buruk semakin dirasakan sejak pemberlakukan Pembatasan Sosial Berskala Besar (PSBB) di beberapa kota di Indonesia. Berdasarkan Pasal 4 Peraturan Pemerintah Republik Indonesia Nomor 21 Tahun 2020 tentang Pembatasan Sosial Berskala Besar Dalam Rangka Percepatan Penanganan Corona Virus Desease 2019 (Selanjutnya disingkat PP No. 21 Tahun 2020), PSBB paling sedikit meliputi peliburan sekolah dan tempat kerja; pembatasan kegiatan keagamaan; dan/atau pembatasan kegiatan di tempat atau fasilitas umum. Adanya pembatasan-pembatasan ini menghambat pergerakan barang dan orang yang tentu berakibat buruk terhadap perekonomian Indonesia di berbagai sektor termasuk sektor perikanan.

Bisnis perikanan di Indonesia merupakan salah satu sektor bisnis yang bernilai besar. Pada tahun 2016, sektor perikanan menyumbang sebesar Rp. 362,12 Miliar pada Pendapatan Negara Bukan Pajak (PNBP). Di tahun 2017, PNBP sektor perikanan meningkat di angka Rp. 491,03 Miliar. Di tahun 2018, PNBP sektor perikanan sedikit menurun di angka $\mathrm{Rp}$. 448,5 Miliar. Terkait penerimaan pajak, penerimaan pajak sektor perikanan di tahun 2014 sebesar Rp. 851 Miliar; Tahun 2016 sebesar Rp. 1,06 Triliun, Tahun 2017 sebesar Rp. 1,3 Triliun, Tahun 2018 sebesar 1,6 Triliun (Nurhayat, 2019). Diakui atau tidak, adanya pandemi Covid-19 memberikan beberapa dampak terhadap bisnis di Indonesia termasuk di sektor perikanan. Dampak yang terjadi dirasakan baik oleh pengusaha maupun nelayan.

Berdasarkan latar belakang di atas, terdapat dua hal yang perlu dikaji dalam tulisan ini yaitu pertama apa dampak pandemi Covid-19 terhadap sektor perikanan di Indonesia. Kedua, bentuk 
kerjasama internasional seperti apakah yang dapat dijalin oleh Indonesia dalam rangka peningkatan perekonomian melalui sektor perikanan di masa pandemi Covid-19.

\section{B. Pembahasan}

\section{Dampak Pandemi Covid-19 Terhadap Sektor Perikanan di Indonesia}

Guna memutus rantai penularan Covid19 di Indonesia, Pemerintah Indonesia meminta warganya untuk menjaga jarak dalam beraktivitas serta mengurangi aktivitas di luar rumah. Google mempublikasikan analisis data lokasi ponsel dari masyarakat dunia termasuk masyarakat Indonesia. Hal ini digunakan untuk mengetahui apakah masyarakat Indonesia benar-benar menerapkan social dan physical distancing serta mengurangi aktivitas di luar. Data menunjukkan bahwa dalam kurun waktu sejak 6 Februari hingga 29 Maret, tren mobilitas masyarakat ke restoran, kafe, pusat perbelanjaan, taman, museum, perpustakaan dan bioskop turun $47 \%$. Tren mobilitas masyarakat Indonesia ke toko bahan makanan dan pasar turun 27\% (Roy, 2020).

Covid-19 membuat masyarakat membatasi kegiatannya. Covid-19 menjadikan arus barang terhambat sehingga mengganggu proses produksi. Tidak sedikit kegiatan usaha yang terkena dampak yang kemudian menyebabkan penghentian operasi baik sementara maupun permanen. Pemutusan Hubungan Kerja (PHK) akhirnya menjadi solusi terakhir yang dipilih oleh pengusaha sebagai solusi dalam kondisi yang serba sulit seperti ini. Pandemi Covid19 memberikan dampak terhadap sektor perikanan di Indonesia di antaranya adalah menurunnya aktivitas tangkap ikan di beberapa Wilayah Pengelolaan Perikanan Negara Republik Indonesia (WPPNRI). Selama tiga bulan terakhir sejak kasus Covid-19 pertama ditemukan di Indonesia telah terjadi penurunan aktivitas tangkap ikan secara drastis yaitu di WPNRI 711, 712, 713 dan 714 (Ambari, 2020). Di lain sisi, kondisi yang demikian memberikan dampak baik terhadap keberlangsungan sumber daya perikanan di wilayah tersebut.

Berkurangnya kegiatan tangkap ikan akibat pandemi Covid-19 tidak hanya dirasakan oleh Indonesia namun juga negara lain seperti India. Kegiatan tangkap ikan di India pada awalnya ditutup seluruhnya dikarenakan adanya wabah Covid-19. Hal ini menimbulkan protes dan tekanan dari masyarakat sipil karena pelarangan kegiatan tangkap ikan sangat berpengaruh terhadap ketersediaan makanan di India. Pada akhirnya penangkapan ikan diizinkan untuk melanjutkan operasi dalam batas tertentu (Bennett, 2020).

Kondisi WPPNRI yang sepi dari aktivitas tangkap ikan oleh nelayan Indonesia memicu Kapal Ikan Asing (KIA) melakukan illegal fishing. Kapal-kapal tersebut sebagian besar berasal dari negara Vietnam, Filipina dan Malaysia. Sebagian kapal-kapal tersebut sejak awal telah menjadikan Indonesia sebagai wilayah tujuan untuk melakukan illegal fishing. Sebagian lainnya melakukan illegal fishing dalam perjalanan pulang ke negara asal setelah pulang dari area penangkapan ikan di zona laut bebas seperti yang dilakukan oleh Kapal Sheng Teng Qun 66 yang berasal dari Taiwan. Kapal tersebut ditemukan di Laut Sulawesi dengan alat tangkap longline yang biasa digunakan untuk menangkap ikan tuna. Kapal tersebut masuk ke Laut Sulawesi dalam perjalanan pulang menuju negara asal dari area penangkapan ikan di Samudera Pasifik. Pada Juli 2019 kapal berbendera Taiwan tersebut terdeteksi sedang berada di Laut Sulawesi dan pada April 2020 kembali terdeteksi sedang berada di Laut Sulawesi. Kapal Sheng Teng Qun 66 berhasil ditangkap oleh Pengawasan Sumber Daya Kelautan dan Perikanan (PSDKP) pada tanggal 21 April 2020.

Dampak kedua adalah berkurangnya permintaan terhadap ikan maupun produk olahan ikan non kaleng. Berkurangnya permintaan terhadap ikan dan produk olahannya disebabkan oleh beberapa hal seperti menurunnya daya beli masyarakat. 
Penyebab lainnya adalah beberapa negara yang biasa mengimpor ikan dan produk olahannya dari Indonesia menghentikan sementara dengan alasan kesehatan maupun menurunnya permintaan konsumen. Selama pandemi Covid-19 ini permintaan dari luar negeri menurun sebanyak 30-40\% (Komalasari, 2020). Seperti efek domino, dengan berkurangnya permintaan terhadap ikan dan produk olahannya, maka membuat harga jual menurun. Kondisi seperti ini mempengaruhi kondisi ekonomi nelayan maupun pengusaha pengolahan ikan.

Semakin hari angka kasus Covid-19 di Indonesia semakin meningkat. Pemerintah memiliki kebijakan untuk menerapkan Pembatasan Sosial Berskala Besar (PSBB) di beberapa wilayah untuk mengurangi penyebaran Covid-19 di Indonesia. Berdasarkan Pasal 2 ayat (1) PP No. 21 Tahun 2020, PSBB membatasi tidak hanya pergerakan manusia namun juga barang. Penerapan PSBB menjadikan arus distribusi ikan dan produk olahan dari satu wilayah di Indonesia ke wilayah lainnya menjadi lambat. Keterlambatan distribusi ikan dan produk olahannya tidak hanya terjadi untuk distribusi melalui jalur darat namun juga melalui jalur laut. Terdapat pembatasan di pelabuhan yaitu nelayan yang akan bersandar harus melaksanakan karantina. Hal ini juga salah satu penyebab nelayan mengurangi aktivitas tangkap ikan (Komalasari, 2020).

\section{Langkah Kementerian Kelautan dan Perikanan dalam Mengurangi Dampak Covid-19}

Beberapa dampak buruk dari pandemi Covid-19 telah dirasakan oleh sektor perikanan di Indonesia terutama sub sektor perikanan tangkap. Industri perikanan tangkap harus mendapat perhatian dari Pemerintah Indonesia karena industri ini merupakan salah satu sumber pertumbuhan ekonomi. Industri perikanan juga merupakan sumber mata pencaharian banyak masyarakat yang terkait dalam industri tersebut seperti nelayan kecil, penjual ikan, pengusaha pengolahan ikan, penjual produk pengolahan ikan, dan semua pihak yang mendapatkan keuntungan dari itu (Wardono, B., Fauzi, A., Fahrudin, and A., Purnomo, 2016). Kementerian Kelautan dan Perikanan (KKP) telah melakukan beberapa upaya untuk meminimalisir dampak buruk pandemi Covid-19 terhadap sektor perikanan di Indonesia.

Menanggapi dampak pandemi Covid-19 terhadap industri perikanan tangkap, KKP telah merevisi target produksi perikanan tangkap tahun 2020. Seperti diketahui sebelumnya, KKP menetapkan target produksi perikanan pada tahun 2020 sebanyak 26,46 juta ton dengan rincian 8,02 juta ton berasal dari perikanan tangkap, 7,45 juta ton dari perikanan budidaya, dan 10,99 juta ton dari rumput laut. Target produksi perikanan tangkap direvisi yang semula sebanyak 8,02 juta ton menjadi 7,7 juta ton.

Upaya lain yang dilakukan KKP untuk mengurangi dampak buruk pandemi Covid19 pada sektor perikanan adalah dengan mengeluarkan Surat Edaran (SE) Menteri Kelautan dan Perikanan tentang Alih Muatan pada Kapal Perikanan. Surat Edaran tersebut menjelaskan bahwa kapal pengangkut ikan yang memiliki Surat Izin Kapal Pengangkut Ikan (SIKPI) dapat mendaratkan hasil tangkapan ikan di pelabuhan perikanan yang baik yang tercantum dalam SIKPI ataupun tidak. Langkah ini diambil untuk mempermudah arus distribusi hasil tangkapan ikan dan dapat dijadikan solusi perluasan pasar penjualan hasil tangkapan ikan. Langkah lain yang dilakukan KKP adalah dengan mempermudah akses perizinan dan fasilitas permodalan kepada semua nelayan dan pelaku usaha pada subsektor perikanan tangkap. Pelayanan pemberian izin dilakukan secara online sehingga lebih aman, cepat, dan efekif dilaksanakan di masa pandemi seperti saat ini.

Covid-19 memberikan dampak pada berkurangnya permintaan atas perikanan tangkap dari pasar luar negeri. Hal ini disebabkan adanya kebijakan lockdown dari beberapa negara importir ikan maupun produk olahan ikan yang berasal dari 
Indonesia. Hasil penelitian menunjukkan, sebagian besar negara yang memilih untuk menerapkan lockdown untuk mencegah penyebaran Covid-19 tidak mempertimbangkan efek penerapan lockdown terhadap rantai pasokan global (Guan D., 2020). Kondisi di atas berakibat pada menumpuknya stok ikan hasil tangkapan nelayan Indonesia.

Solusi yang ditawarkan oleh KKP adalah penerapan Sistem Resi Gudang (SRG) atau Sistem Tunda Jual. Hal ini dilakukan dengan tujuan mencegah anjloknya harga ikan di pasaran. Sistem ini tidak sepenuhnya efektif karena ketersediaan cold storage tidak cukup untuk menampung hasil tangkapan ikan dari nelayan. Sebagai solusi dari over supply hasil tangkapan ikan, KKP menjalin kerjasama dengan Kementerian sosial dan pemerintah daerah dengan memasukkan produk olahan ikan ke dalam paket bantuan sosial atau Bantuan Pangan Non Tunai (BPNT). KKP juga meminta pada Kemensos untuk memasukkan para nelayan, pembudidaya ikan, dan petambak yang tergolong miskin untuk mendapatkan bantuan Program Keluarga Harapan (PKH) dan Bantuan Pangan Non Tunai (BPNT) (Yuliastuti, 2020).

Solusi lain terhadap penumpukan stok hasil tangkapan ikan di gudang penyimpanan atau cold storage adalah dengan menggalakkan kembali masyarakat Indonesia untuk gemar memakan ikan atau produk olahannya. Gerakan ini diharapkan dapat meningkatkan penjualan hasil tangkapan ikan maupun produk olahannya. Kampanye gemar memakan ikan dilakukan dengan menunjukkan manfaat dari konsumsi ikan dalam meningkatkan daya tahan tubuh untuk menghadapi pandemi Covid-19.

\section{Kerjasama Internasional untuk Peningkatan Perekonomian Indonesia di Sektor Perikanan di Masa Pandemi Covid-19}

Berdasarkan United Nations Convention on the Law of the Sea 1982 (UNCLOS 1982), negara pantai memiliki kedaulatan dan hak berdaulat dalam hal eksplorasi dan eksploitasi sumber daya laut tergantung pada zona lautnya. Sama halnya dengan Indonesia, sebagai negara kepulauan, pengelolaan sumber daya laut mulai dari perairan kepulauan hingga pada Zona Ekonomi Eksklusif menjadi kewenangan darinya. Pemerintah Indonesia harus berupaya semaksimal mungkin dalam mengelola sumber daya laut agar pengelolaan perikanan dapat memberikan kemakmuran terhadap rakyat sesuai dengan yang diamanahkan oleh Pasal 33 ayat (3) Undang-undang Dasar 1945. Segala kebijakan yang diambil dalam hal pengelolaan perikanan seyogyanya dapat memberikan keadilan sesuai dengan tujuan hukum itu dibuat (Prasetyo, 2007).

Adanya pandemi Covid-19, memberikan tantangan tersendiri bagi Pemerintah Indonesia dalam upaya meningkatkan perekonomian melalui sektor perikanan. Bisnis perikanan tangkap merupakan suatu kegiatan ekonomi sehingga dalam menjalankan aktivitasnya selalu didasarkan pada pertimbangan ekonomi agar usaha yang dijalankan mendapatkan keuntungan. Salah satu prinsip ekonomi yang dapat dijadikan dasar pertimbangan adalah efisiensi (Kusumawati, P ; Rosyid, A ; Kohar, 2020). Pandemi Covid-19 menjadi alasan besar dalam inefisiensi dalam bisnis perikanan tangkap yang tidak hanya merugikan para nelayan namun juga pengusaha pengolahan ikan.

Salah satu faktor yang mempengaruhi peningkatan bisnis perikanan di dunia adalah kemudahan transportasi dan distribusi logistik (Asche F., 2014). Dengan adanya pandemi Covid-19 serta kebijakan lockdown dari beberapa negara tentunya memberikan pengaruh terhadap bisnis perikanan dunia, termasuk di Indonesia. Dibutuhkan kerjasama internasional antara Indonesia dengan negara-negara lain dalam hal penanggulangan dampak buruk pandemi Covid-19 terhadap sektor perikanan di indonesia. Kerjasama internasional dibutuhkan karena bisnis perikanan di Indonesia berkaitan erat dengan pasar luar 
negeri yang bergantung dengan kebijakan dari negara tujuan. Alasan lainnya adalah kondisi geografis Indonesia yang berbatasan dengan 10 negara (India, Thailand, Malaysia, Singapura, Australia, Filipina, Republik Palau, Vietnam, Timor Leste, dan Papua Nugini) dimana Indonesia dalam urusan laut dan sumber daya laut tidak bisa terlepas dari kepentingan negara lain terutama negara yang berbatasan laut secara langsung.

Sebagaimana disebutkan sebelumnya, salah satu dampak pandemi Covid-19 adalah menurunnya jumlah nelayan yang melaut di beberapa WPPNRI. WPPNRI yang sepi dari kegiatan tangkap ikan oleh kapal nelayan Indonesia memicu KIA untuk melakukan illegal fishing. Kerjasama internasional yang perlu disepakati oleh Indonesia dalam rangka pengurangan dampak pandemi Covid-19, pertama adalah Kerjasama billateral untuk pencegahan dan pengurangan Illegal, Unreported, and Unregulated (IUU) Fishing. Selama periode kepemimpinan Edhy Prabowo di KKP, terdapat sebanyak 35 KIA yang ditangkap karena melakukan illegal fishing. Kapal tersebut terdiri dari 17 kapal berbendera Vietnam, 9 kapal berbendera Filipina, 8 kapal berbendera Malaysia dan 1 kapal berbendera Taiwan.

Illegal fishing yang terjadi dewasa ini telah berubah cara beroperasinya dibandingkan dengan cara beroperasi di tahun 1990-an. Kejahatan illegal fishing saat ini telah menjadi "a highly sophisticated form of transnational organized crime" yang salah satu cirinya adalah kontrol pergerakan kapal yang modern dan peralatan yang modern (Fernandes, 2017). Beberapa modus illegal fishing dilakukan di antaranya dengan cara memindahkan tangkapan dari satu kapal ke kapal lainnya di tengah laut, menggunakan bendera yang berbeda, menonaktifkan vessel monitoring, dan membawa dokumen-dokumen palsu (Widjaja, S., Long, T., and H. Wirajuda, 2019). Kerjasama antar negara menjadi salah satu strategi dalam penanganan kejahatan illegal fishing (Yanti, B. V. I. ,
Koeshendrajana, S., Arthatiani, 2013). Kerjasama internasional dalam memberantas IUU Fishing menjadi penting karena dalam pelaksanaannya, IUU Fishing dilakukan secara terorganisir dimana melibatkan pihak-pihak yang berasal dari negara yang berbeda. Kapal yang digunakan untuk IUU Fishing biasanya melakukan tangkap ikan secara illegal tidak hanya di perairan satu negara. Banyak pihak yang terlibat di kejahatan IUU Fishing seperti nelayan, pemilik kapal, pihak yang menampung ikan hasil tangkapan, pihak yang membeli ikan hasil tangkapan, dan pihak yang mendanai kegiatan IUU Fishing. IUU Fishing juga sangat erat kaitannya dengan kejahatan lain seperti perbudakan, pencucian uang, perdagangan orang, penyelundupan senjata, penyelundupan hewan yang dilindungi, dan penyelundupan narkoba.

Alasan lain mengapa diperlukan kerjasama internasional dalam pemberantasan IUU Fishing adalah karena kerjasama akan memudahkan dalam proses penyidikan. Apabila kerjasama sudah terbentuk akan mudah untuk proses pertukaran informasi. Informasi yang dimaksud dapat berupa informasi mengenai pemilik kapal. Hal ini dilakukan agar pemilik kapal baik individu maupun badan hukum dapat dimintai pertanggungjawaban hukum atas kejahatan IUU Fishing mengingat proses hukum atas kejahatan IUU Fishing di Indonesia tidak sampai menyentuh pada pemilik kapal. Informasi lain yang diperlukan adalah mengenai history lalu lintas kapal. Hal ini untuk mengetahui kapal telah melintas dan melakukan tangkap ikan di perairan mana saja.

Telah ada persetujuan yang dibuat oleh negara anggota Food and Agriculture Organization (FAO) untuk pemberantasan IUU Fishing yaitu Port State Measure Agreement to Prevent, Deter, Eliminate Illegal, Unreported, and Unregulated Fishing (untuk selanjutnya disingkat PSMA). Indonesia telah meratifikasi PSMA melalui Peraturan Presiden No. 43 Tahun 2016. PSMA berisi ketentuan-ketentuan 
yang mewajibkan negara pelabuhan untuk melakukan beberapa hal guna untuk pencegahan dan pengurangan IUU Fishing. Tidak hanya itu, isi dari PSMA juga dapat menghindarkan proses kejahatan perdagangan orang terjadi. PSMA juga dijadikan dasar adanya pertukaran informasi yang dibutuhkan dalam penanganan IUU Fishing baik antara sesama negara anggota PSMA maupun dengan Food and Agriculture Organization of the United Nations (FAO) atau dengan organisasi internasional dan regional lainnya.

Berdasarkan Art. 8 PSMA Negara Pelabuhan, sebelum mengizinkan kapal berlabuh di pelabuhannya, harus memeriksa informasi di lampiran A dari nakhkoda kapal. Informasi-informasi ini terdiri dari identifikasi kapal, data terkait ikan yang ada di kapal, dan izin operasional kapal. Pelaksanaan atas persetujuan ini akan bisa menghambat dan menghalangi masuknya ikan ilegal ke pasar nasional maupun internasional. PSMA juga dapat digunakan untuk melindungi Anak Buah Kapal (ABK) dari pelanggaran hak asasi manusia (HAM), sebagaimana tercantum dalam Art. 13 PSMA. Berdasarkan pasal tersebut, Negara Pelabuhan harus mensyaratkan nakhoda kapal untuk memberikan semua informasi yang diperlukan, dan menyajikan materi dan dokumen yang relevan, termasuk kondisi kru kapal. Ratifikasi terhadap PSMA menjadi penting karena implementasi PSMA dapat mencegah ikan hasil IUU Fishing masuk ke dalam Negara Pelabuhan.

Dalam rentang mulai tahun 2014 hingga tahun 2020 terdapat 4 negara yang paling banyak melakukan IUU Fishing di perairan Indonesia yaitu Vietnam, Filipina, Malaysia, dan Thailand. Dari keempat negara tersebut, hanya Malaysia yang belum meratifikasi PSMA. Sebagai negara bendera asal kapal yang sering melakukan IUU Fishing di perairan Indonesia, apabila keempat negara tersebut menjadi negara anggota PSMA seharusnya akan mempermudah dalam pemberantasan IUU Fishing. Namun sejak entry into force pada Tanggal 5 Juni 2016, masih banyak kapal yang berasal dari empat negara di atas yang melakukan illegal fishing di perairan Indonesia. Terdapat beberapa negara yang berbatasan laut dengan Indonesia belum meratifikasi PSMA selain Malaysia, seperti Singapura, Timor Leste, India, dan Papua Nugini.

Dalam kerjasama bilateral terkait pemberantasan IUU Fishing, Indonesia belum memiliki kerjasama dengan Malaysia. Indonesia dan Malaysia baru menyepakati tata cara perlakuan terhadap nelayan dari masing-masing ketika memasuki dan melakukan tangkap ikan di negaranya. Kesepakatan tersebut tertuang dalam MoU antara Indonesia dengan Malaysia tentang Common Guidelines Concerning Treatment of Fishermen by Maritime Law Enforcement Agencies of Malaysia and the Republic of Indonesia. Kesepakatan ini hanya berlaku untuk nelayan-nelayan yang melakukan tangkap ikan di perairan yang belum ditentukan batas wilayah antara kedua negara tersebut. Indonesia membutuhkan kerjasama dengan Malaysia dalam pemberantasan IUU Fishing karena banyak KIA berbendera Malaysia yang melakukan illegal fishing dan berdalih bahwa mereka melakukan tangkap ikan di grey area.

Kapal berbendera Vietnam menjadi kapal terbanyak yang melakukan IUU Fishing di perairan Indonesia meski Vietnam merupakan negara peratifikasi PSMA. Dengan diratifikasinya PSMA oleh Vietnam, maka Vietnam memiliki kewajiban untuk melakukan pencegahan hasil tangkapan IUU Fishing masuk ke pelabuhannya.Vietnam telah menyepakati kerjasama dengan Indonesia melalui Joint Communique Between Republic of Indonesia and the Socialist Republic of Vietnam pada tanggal 14 september 2011 guna memberantas IUU Fishing. Dalam Point 9 Joint Comunique tersebut telah disepakati oleh kedua negara untuk menguatkan kerjasama dalam bidang kelautan dan perikanan termasuk pencegahan dan pengurangan IUU Fishing. Pada 11 September 2018 telah disepakati rencana kerjasama melalui Joint Communique on Voluntary International Cooperation to 
Combat Illegal, Unreported, and Unregulated IUU Fishing and to Promote Sustainable Fisheries Governance. Kedua negara bermaksud untuk memperkuat kerjasama di antara keduanya maupun dengan organisasi internasional dalam meningkatkan upaya untuk memerangi IUU Fishing melalui pertukaran informasi. Keduanya juga bekerjasama untuk menciptakan mekanisme koordinasi dan pertukaran informasi terkait kapal penangkap ikan yang diduga melakukan IUU Fishing.

Kerjasama juga dijalin antara Badan Keamanan Laut Republik Indonesia (BAKAMLA) dan Vietnam Coast Guard (VCG) melalui Letter of Intent to Enhance Cooperation Beetween BAKAMLA and Vietnam Coast Guard pada Agustus 2017. Kesepakatan berisi kerjasama untuk memperkuat jalur komunikasi di antara para pihak. Keduanya juga menyepakati adanya pertukaran informasi dan merahasiakan informasi yang didapat kepada pihak ketiga tanpa persetujuan tertulis.

Di tahun 2018, Indonesia dan Vietnam menyepakati Plan of Action for the Implementation of the Strategic Partnership Between the Socialist Republic of Vietnam and Republic of Indonesia. Kerjasama di beberapa bidang telah direncanakan dan disepakati oleh kedua negara termasuk perihal pencegahan dan pengurangan IUU Fishing. Beberapa hal ditekankan dalan dokumen tersebut yaitu kedua negara sepakat untuk mengimplementasikan isi dari Joint Communique on Voluntary International Cooperation to Combat Illegal, Unreported, and Unregulated IUU Fishing and to Promote Sustainable Fisheries Governace 2018. Kedua negara akan memperkuat kerjasama dan koordinasi dalam pencegahan dan pengurangan IUU Fishing melalui pertukaran informasi serta pertukaran praktik terbaik dalam pengelolaan perikanan dan regulasi tentang perikanan.

Filipina juga menjadi salah satu negara bendera kapal yang banyak melakukan IUU Fishing di perairan Indonesia. Indonesia, melalui Kepolisian Negara Republik Indonesia (POLRI) menjalin kerjasama pada tahun 2017 dengan Kepolisian Nasional Filipina melalui Memorandum of Understanding Between the Indonesian National Police and the Philippine National Police on Cooperation in Preventing and Combating Transnational Crime and Capacity Building. Kedua pihak sepakat untuk bekerjasama dalam mencegah dan memerangi transnasional crime dimana termasuk pencurian ikan (illegal fishing). Beberapa bentuk kerjasama di antaranya adalah saling bertukar informasi dan dokumen intelijen serta melakukan kegiatan kepolisian bersama.

Di tahun 2019, Indonesia melalui BAKAMLA menjalin kerja sama dengan Filipina dengan menandatangani Memorandum of Understanding between Maritime Security Agency of the Republic of Indonesia (BAKAMLA) and the Philippine Coast Guard (PCG) on Maritime Security. Kedua negara sepakat untuk menjalin kerjasama di bidang keamanan maritim diantaranya seperti bertukar informasi serta berbagi praktik terbaik di bidang kemaanan maritim serta melaksanakan patroli secara terkoordinir. Kerjasama ini dapat digunakan sebagai upaya untuk menjaga perairan masing-masing dari tindak kejahatan IUU Fishing.

Dengan Thailand, Indonesia juga menjalin kerjasama di bidang pertahanan dan menjadikan keamanan laut menjadi salah satu ruang lingkup kerjasama. Pada Mei 2015 keduanya menyepakati Agreement between the Government of the Republic of Indonesia and the Government of the Kingdom of Thailand on Cooperation in the Field of Defence. Dalam kesepakatan tersebut tidak dijelaskan lebih lanjut mekanisme kerjasama dalam hal keamanan laut, namun pertukaran informasi mejadi salah satu hal yang disepakati oleh kedua negara.

Kerjasama Indonesia dengan negara lain khususnya negara yang berbatasan laut dengannya atau negara-negara dimana asal kapal yang banyak melakukan IUU Fishing 
di perairan Indonesia seperti Vietnam, Filipina, Malaysia, dan Thailand harus diperkuat mengingat masih banyaknya kapal yang berasal dari keempat negara tersebut yang ditangkap karena telah melakukan $I U U$ Fishing di perairan Indonesia. Negara yang bekerjasama harus bekerja keras untuk mencegah masuknya ikan hasil IUU Fishing di pelabuhannya. Hal tersebut dapat digunakan sebagai salah satu cara untuk mengurangi praktik IUU Fishing dengan merusak pasar atau membuat hasil tangkapan tidak laku di pasaran. Mekanisme yang dapat digunakan adalah dengan meminta dokumen dan keterangan dari nakhkoda kapal terkait asal usul ikan yang diperoleh. Mekanisme yang demikian juga digunakan dalam PSMA.

Pandemi Covid-19 yang menyebabkan krisis kesehatan global yang kemudian berdampak pada ekonomi global menjadikan negara-negara di dunia harus mundur dengan rencana-rencana strategis yang semula direncanakan. Rencana strategis tersebut digantikan dengan kebijakan tanggap darurat dengan memobilisasi semua sumber daya untuk mengatasi permasalahan Covid-19 (Muhyiddin, 2020). Hal tersebut juga turut dirasakan oleh Indonesia yang memutuskan untuk mengalokasikan sejumlah anggaran di beberapa kementerian untuk penanganan Covid-19. Langkah Pemerintah Indonesia yang memotong anggaran Kementerian Pertahanan diakui atau tidak pasti memberikan dampak terhadap kegiatan operasional penjagaan atau patroli di perairan Indonesia. Di lain sisi, salah satu penyebab masih banyaknya kasus IUU Fishing di perairan Indonesia adalah masih lemahnya pengawasan di perairan Indonesia (Albar, 2019). Oleh karena itu perlu dipikirkan langkah atau solusi lain untuk meminimalisir dampak buruk pemotongan anggaran Kementerian Pertahanan terhadap kemanan laut Indonesia.

Kerjasama internasional kedua yang dapat dilakukan oleh Indonesia adalah memperkuat pasar ekspor terutama di wilayah Asia Tenggara. Indonesia dapat memanfaatkan forum-forum Association of South East Asian Nations (ASEAN) untuk memastikan rantai pasokan (supply chain) makanan atau bahan makanan di wilayah Asia Tenggara. Indonesia dapat memanfaatkan pasar-pasar luar negeri untuk memasarkan produk ikan dan olahan ikan di negara-negara ASEAN.

Indonesia bersama negara-negara anggota ASEAN telah menyelenggarakan Special ASEAN Summit on Coronavirus Disease 2019 (COVID-19) pada tanggal 14 April 2020. Pertemuan tingkat kepala negara ini membahas langkah bersama dalam menangani dampak Covid-19, memastikan pasokan barang atas makanan, obat-obatan, dan barang esensial lainnya di kawasan ASEAN, dan pemanfaatan sejumlah kerjasama yang dimiliki ASEAN Plus Three (APT). APT adalah negara-negara ASEAN ditambah dengan tiga negara di luar wilayah regional Asia Tenggara yaitu China, Jepang, dan Korea Selatan. Dari pertemuan ini dihasilkan pernyataan bersama dari negaranegara anggota ASEAN yaitu Declaration of the Special ASEAN Summit on Covid-19 (14 April 2020). Melalui deklarasi ini, negara-negara anggota ASEAN berkomitmen untuk memperkuat kerjasama di bidang kesehatan dan melindungi masyarakat ASEAN dari Covid-19 dengan cara bertukar informasi secara transparan mengenai situasi dan kondisi saat ini, praktik terbaik atas penanganan Covid-19, serta perkembangan penelitian atas obat dan vaksin Covid-19. Deklarasi ini juga mempertegas kembali isi dari the ASEAN Economic Ministers's Joint Statement on Strengthening ASEAN's Resilience on Response to the Outbreak of Covid-19 untuk tetap berkomitmen untuk menjaga pasar ASEAN tetap terbuka untuk perdagangan dan investasi, memastikan tidak adanya hambatan yang tidak perlu dalam perdagangan, meningkatkan kerja sama di antara negara-negara anggota ASEAN dan juga dengan mitra eksternal ASEAN dengan tujuan untuk memastikan keamanan pangan, memperkuat ketahanan dan keberlanjutan rantai pasokan regional, terutama untuk 
makanan, komoditas, obat-obatan, pasokan medis dan esensial.

Di hari yang sama, APT berhasil membentuk Joint Statement of the Special ASEAN Plus Three (APT) Summit on Covid19 yang isinya kurang lebih sama dengan Declaration of the Special ASEAN Summit on Covid-19. APT berkomitmen untuk menjalin kerjasama dalam penanganan dan pengurangan dampak Covid-19 yang salah satunya dengan cara pertukaran informasi mengenai situasi dan kondisi terkini serta penanganan terbaik atas Covid-19. Berkaitan dengan perdagangan, APT juga sepakat untuk menjaga pasar APT tetap terbuka untuk perdagangan dan investasi, dan meningkatkan kerja sama di antara mereka dengan tujuan untuk memastikan keamanan pangan, memperkuat ketahanan dan keberlanjutan rantai pasokan regional, terutama untuk makanan, komoditas, obatobatan, pasokan medis dan esensial. APT juga sepakat untuk tidak memberikan hambatan-hambatan yang tidak perlu dalam perdaganagan internasional yang tidak sesuai dengan aturan-aturan dalam Worl Trade Organization (WTO).

Indonesia dapat memanfaatkan komitmen kerja sama baik di antara negaranegara anggota ASEAN maupun dengan tiga negara mitra. Pemerintah Indonesia dapat meningkatkan dan mengembangkan jangkauan pasar ekspor ikan dan produk olahannya mengingat Jepang adalah salah satu dari negara pengimpor terbanyak atas ikan dan produk olahannya. Setiap tahunnya, Jepang mengimpor sekitar 5,5 juta ton ikan dan olahannya. Jepang juga merupakan pasar terbesar di dunia untuk ikan tuna (Swarts, 2010). Hal ini dapat dimanfaatkan oleh pemerintah Indonesia untuk menaikkan kembali ekspor ikan dan produk olahannya. Pemerintah Indonesia dapat meyakinkan negara-negara anggota ASEAN dan tiga negara mitra bahwa ikan dan produk olahan ikan dari Indonesia telah memenuhi standar kesehatan dan kebersihan mengingat di masa pandemi Covid-19 kesehatan dan kebersihan merupakan prioritas utama bagi negara-negara.
Saat ini Indonesia memiliki sistem sertifikasi kesehatan ikan dan kebersihan. Sertifikasi kesehatan ikan menjadi bagian tugas dari Badan Karantina Ikan, Pengendalian Mutu, dan Keamanan Hasil Perikanan Kementerian Kelautan dan Perikanan (BKIPM KKP). Sertifikasi ikan dilaksanakan melalui proses karantina dan pengambilan sampel untuk diuji secara klinis dan laboratoris. Apabila produk yang akan diekspor telah lulus uji dan bebas hama penyakit sesuai yang dipersyaratkan negara pengimpor, maka akan dikeluarkan Sertifikat Kesehatan dan Produk Perikanan (Health Certificate for Fish and Fish Product). Sertifikasi kesehatan ikan dapat meyakinkan negara lain untuk impor ikan dan produk olahan ikan dari Indonesia. Angka ekspor di sektor perikanan akan semakin naik. Naiknya ekspor di sektor perikanan akan membawa dampak baik dari segi ekonomi para nelayan dan pengusaha pengolahan ikan

\section{Simpulan}

Kesimpulan dari tulisan ini adalah pandemi Covid-19 memberikan dampak positif dan negatif terhadap sektor perikanan Indonesia. Pandemi Covid-19 menjadikan nelayan mengurangi aktivitas tangkap ikan. Bahkan di beberapa WPPNRI sangat jauh berkurang jumlah nelayan yang melakukan tangkap ikan. Sepinya WPNRI memancing KIA untuk masuk ke perairan Indonesia dan melakukan tangkap ikan secara illegal. Di lain sisi,berkurangnya aktifitas tangkap ikan oleh nelayan Indonesia memberikan sedikit dampak baik untuk mengembalikan keberlanjutan sumber daya perikanan di Indonesia. Dampak lainnya adalah berkurangnya permintaan atas ikan dan produk olahannya baik di pasar domestik maupun luar negeri. Hal ini menyebabkan over supply tangkapan ikan yang menyebabkan harga ikan menurun sehingga mempengaruhi perekonomian nelayan dan pengusaha pengolahan ikan. Adanya PSBB sebagai langkah untuk menghentikan penyebaran Covid-19 juga memperlambat 
arus distribusi ikan dan produk pengolahan ikan.

Kerjasama internasional yang dapat dilakukan oleh Indonesia adalah dengan menyepakati kerjasama pemberantasan IUU Fishing dengan negara yang berbatasan laut dengannya terutama negara yang banyak kapalnya melakukan IUU Fishing di perairan Indonesia. Kerjasama lain yang dapat dilakukan adalah dengan memanfaatkan forum-forum ASEAN untuk menjalin kerjasama perdagangan terutama sektor perikanan. Kerja sama diwujudkan dengan membentuk persetujuan yang berisi komitmen antara negara-negara anggota ASEAN dan tiga negara mitra untuk menjamin supply chain atas produk makanan termasuk ikan dan produk olahannya.

\section{DAFTAR PUSTAKA}

Acikgoz O; Gunay, A. (2020). The Early Impact of the Covid-19 Pandemic on the Global and Turkish Economy. Turkish Jornal of Medical Sciences, 50(3), 520-526.

Alam, S. O. (2020). Perkembangan Virus Korona Setelah WHO Tetapkan Status Pandemi. Detik.Com. https://health.detik.com/beritadetikhealth/d-4936821/perkembanganvirus-corona-setelah-who-tetapkanstatus-pandemi

Albar, M. F. (2019). Koherensi Pengaturan Illegal, Unreported, and Unregulated Fishing di Indonesia. Jurnal RechtVinding, 8(2), 245-264.

Ambari, M. (2020). Memetakan Dampak Positif dan Negatif Pandemi Covid-19 pada Kapal Ikan. Mongabay. https://www.mongabay.co.id/2020/05/2 1/memetakan-dampak-positif-dannegatif-pandemi-covid-19-pada-kapalikan/

Arlinta, D. (2020). WHO Tetapkan Darurat Kesehatan Global Infeksi Virus Korona. Kompas. https://kompas.id/baca/humaniora/keseh atan/2020/01/31/penyakit-menular-whotetapkan-darurat-kesehatan-globalinfeksi-virus-korona/\%0A\%0A

Asche F. (2014). Exchange Rates and the Seafood Trade. The Globe Fish Reserach Programme of Food and Agriculture (FAO), 113.

Baskara, B. (2020, April 18). Rangkaian Peristiwa Pertama Covid 19. Kompas. https://bebas.kompas.id/baca/riset/2020/ 04/18/rangkaian-peristiwa-pertamacovid-19/

Bennett, N. J. E. al. (2020). The COVID-19 Pandemic, Small-Scale Fisheries and Coastal Fishing Communities. Coastal Management Journal, 48(4), 336-347.

Fernandes, I. (2017). Tinjauan Yuridis Illegal Fishing di Indonesia Berdasarkan Undang-undang Perikanan. Jurnal Hukum Respublica, 17(1), 189-209.

Guan D., et. al. (2020). Global Supply Chain Effects of Covid-19 Control Measures. Natur Human Behaviour, 4(June), 577-587.

Komalasari, T. D. (2020). Pandemi Covid19, Industri Perikanan Tangkap Alami Tekanan dari Hulu hingga Hilir. Pikiran Rakyat. https://www.pikiranrakyat.com/ekonomi/pr-

01379885/pandemi-covid-19-industriperikanan-tangkap-alami-tekanan-darihulu-hingga-hilir

Kusumawati, P ; Rosyid, A ; Kohar, A. (2020). Upaya Peningkatan Kinerja Usaha Perikanan Melalui Peningkatan Lingkungan Usaha pada Alat Tangkap Cantrang (Boat Seine) danKebijakan Pemerintah Daerah di Kabupaten Rembang. Jurnal Saintek Perikanan, 6(1), 36-45.

Muhyiddin. (2020). Covid-19, New Normal dan Perencanaan Pembangunan di Indonesia. The Indonesian Journal of Development Planning, 4(2), 240-152. 
Muttaqin, A. (2020, September 17). Update Virus Corona Nasional 17 September: Tambah 3.963 Kasus, Total 288/993, NTB, 9 Pasien Baru. Tribun Mataram. https://mataram.tribunnews.com/2020/0 9/17/update-virus-corona-nasional-17september-2020-tambah-3963-kasustotal-288993-ntb-9-pasien-baru?pag

Nurhayat, W. (2019, September 4). KKP Tanggapi DPR: Baru di Era Susi PNBP Perikanan Ditarget Rp 900 M. Retrieved from.

Kumparan. https://kumparan.com/kumparanbisnis/k kp-tanggapi-dpr-baru-di-era-susi-pnbpperikanan-ditarget-rp-900-m1rnXqpzeMYy/full

Ozili, P.K.; Arun, T. (2020). Spillover of Covid-19: Impact on the Global Economy. SSRN Electronic Journal. https://papers.ssrn.com/sol3/papers.cfm ?abstract_id=3562570.\%0A\%0A

Prasetyo, T.; A. H. B. (2007). Ilmu Hukum \& Filsafat Hukum. Pustaka Pelajar.

Putri, G. S. (2020). Update Corona Dunia 2 Juni: 6,38 Juta Orang Terinfeksi, 2,9 Juta Sembuh. Kompas. https://www.kompas.com/sains/read/20 20/06/02/092306223/update-coronadunia-2-juni-638-juta-orang-terinfeksi29-juta-sembuh

Roy. (2020, April 3). Patuhkah Warga RI Terapkan Social Dstancing selama Corona?. Retrieved from. CNBC Indonesia. https://www.cnbcindonesia.com/tech/20 200403141930-37-149636/patuhkahwarga-ri-terapkan-social-distancingselama-corona $\% 0 \mathrm{~A} \% 0 \mathrm{~A}$

Swarts, W. et. a. (2010). Sourcing Seafod for the Three Major Markets: the EU, Japan, and the USA. Marine Policy, 34, $1366-1373$.

Wardono, B., Fauzi, A., Fahrudin, and A., Purnomo, A. H. (2016). Value Added Business Based on Small Scale of Fisheries: A Case Study on Northern And Southern Coast of Java (Lamongan and Pelabuhan Ratu Regency). Indonesia. International Journal of Scientific \& Technology Research, 5(2), 135-139.

Widjaja, S., Long, T., and H. Wirajuda, H. (2019). Illegal, Unreported and Unregulated Fishing and Associated Drivers. World Resources Institute.

Yanti, B. V. I. , Koeshendrajana, S., Arthatiani, F. Y. (2013). Peran Diplomasi Kelautan Dan Perikanan Sebagai Bagan Upaya Menanggulangi Perikanan Illegal di Indonesia. Jurnal Kebijakan Sosial Ekonomi Kelautan Dan Perikanan, 3(1), 39-45.

Yuliastuti, N. (2020, April 5). KKP Ingin Kemensos Masukkan Nelayan Sebagai Penerima Bantuan. Antaranews. https://www.antaranews.com/berita/140 4474/kkp-ingin-kemensos-masukkannelayan-sebagai-penerima-bantuan 